\title{
Addressing Canada's Commercialization Crisis and Shortage of Venture Capital: Will the Federal Government's Solution Work?
}

\author{
Stephen A. Hurwitz
}

\author{
"Being a philosopher, I have a problem for every solution." \\ Robert Zend (1929-1985) \\ Poet, fiction writer, and multi-media artist
}

\begin{abstract}
Lack of funding is a major challenge to innovation in Canada's emerging technology industry. This article will focus on this supply-side challenge within the complex venture capital ecosystem and discuss: i) the current shortage of venture capital available to commercialize Canada's R\&D; ii) the causes and consequences of that venture capital shortage; iii) how the federal government will address this shortage through its innovative 2013 Venture Capital Action Plan, which commits $\$ 400$ million and seeks to raise at least another $\$ 800$ million from outside investors; and iv) how a separate decision in the federal 2013 budget to phase out federal tax credits for labour-sponsored venture capital funds could imperil the 2013 Venture Capital Action Plan.
\end{abstract}

\section{Introduction}

Canada has an abundance of great ideas and the worldclass R\&D to develop them. This abundance is hardly surprising given Canada's outstanding institutions of higher learning, exceptional research centres, and highly educated population. It is also a result of federal and provincial governments' $R \& D$ funding programs that are among the most generous and progressive anywhere, and, as a percentage of Canada's GDP, which is among the highest in the world. However, Canada has a serious shortage of that specialized funding source venture capital - that is essential to commercializing that world-class $R \& D$ into products, jobs, and exports. This is Canada's commercialization crisis.

Because of the critical role venture capital plays in commercializing a country's $R \& D$, this article will focus on the supply-side challenge within the complex venture capital ecosystem. Simply put, traditional sources of institutional financing such as banks are largely unavailable to emerging technology companies because they typically have few bankable hard assets such as equipment, inventory, and buildings; no positive cash flow; little, if any, operational history; and profits, and sometimes even revenues, that may be many years away.

Venture capital is pretty much the only institutional private financing available to assume the risks of funding the commercialization of unproven technologies. That is why it is called risk capital. But, in addition to capital, top-tier venture capitalists also bring specialized capabilities that even the most gifted young entrepreneur often lacks but are essential for successfully commercializing R\&D. These capabilities include entrepreneurial experience in operating companies, domain industry expertise, and extensive networks in global customer and capital markets.

This article focuses on Canada's shortage of venture capital and how it limits the commercialization of the country's technology innovations. The next section highlights the extent of this shortage and examines its underlying causes. Then, an overview is provided of the 


\title{
Addressing Canada's Commercialization Crisis and Shortage of Venture Capital
}

\author{
Stephen A. Hurwitz
}

federal government's 2013 Venture Capital Action Plan, which is designed to address this shortage. This is followed by a discussion of the impact of a separate decision in the federal 2013 budget to phase out federal tax credits for labour-sponsored venture capital funds. Finally, conclusions are offered.

\section{How Serious is Canada's Venture Capital Shortage?}

Like venture capital industries in many places in the world, including the United States and Europe, Canada's venture capital industry in recent years has faced challenging times. Statistics from Canada's Venture Capital \& Private Equity Association (CVCA; cvca.ca) reveal that, in 2010 and 2011, the Canadian venture capital industry experienced its worst fundraising in more than 16 years. Although there was a significant uptick in fundraising from $\$ 1.0$ billion in 2011 to $\$ 1.8$ billion in 2012 (CVCA, 2012; tinyurl.com/kddkw2k), it was still well below the $\$ 3.9$ billion achieved in Canadian fundraising in 2001 (BDC, 2010; tinyurl.com/7wg7ouw), with little assurance that the improved 2012 levels will recur in 2013. The levels of venture capital investment in Canada in both 2011 and 2012 were $\$ 1.5$ billion (CVCA, 2012; tinyurl.com/kddkw2k); these levels are a far cry from the \$3.7 billion investment level in 2001 (BDC, 2010; tinyurl.com/7wg7ouw).

Even when Canadian companies do obtain venture capital financing, it is often in amounts insufficient to meet their capital needs. In 2011 and 2012, Canadian companies backed by venture capital received on average only 44 cents in funding for every dollar of such funding received by US companies (CVCA, 2012; tinyurl.com/ kddkw2k). Yet, these undercapitalized Canadian companies must compete in the same global market as their farbetter financed US competitors, not to mention those from other countries. And, Canadian companies that do get funded encounter formidable difficulty in achieving venture capital follow-on financing, which is in especially short supply in Canada.

As a result, rather than blossoming into industry leaders, the author has witnessed many of these promising capital-starved but R\&D-rich companies being sold early in their lifecycles - and at low prices - and being then moved, along with the future jobs they will create, to the United States.

\section{Understanding the shortage}

No viable solution to the shortage of venture capital can be devised without understanding its underlying causes. In the author's view, the following conditions and actions have limited the currently availability of venture capital in Canada:

1. During roughly the past decade, the Canadian venture capital industry has performed poorly. It did not help that, during this period, there was a burst technology bubble, a serious recession, and insufficient liquidity opportunities (i.e., initial public offerings, mergers, or acquisitions).

2. Because of this poor performance, large Canadian institutional investors that had funded Canadian venture capital firms withdrew from the venture capital asset class.

3. At the same time, venture capital firms in the United States, which in prior years had accounted for as much as $40 \%$ of all venture capital funding in Canada, greatly reduced their investments in Canada because of their own fundraising and portfolio company troubles in the United States.

4. Unlike the US venture capital industry, with its longstanding investment experience developed over 60 years, Canada's venture capital industry is relatively young and less experienced, with more than $92 \%$ of its venture capital firms formed after 1994 (CVCA, 2009; tinyurl.com/cba2fw).

5. The vast majority of Canadian venture capital firms are sub-scale in size (i.e., well below $\$ 100$ million) with inadequate funds to fully participate in the major investments needed to grow and scale production of their portfolio companies and to accelerate their sales to enter world markets. These sub-scale venture capital firms are inadequately integrated into the global venture capital ecosystem and do not have the funds to systematically invest large amounts over time in potential big winners through investment networks with other venture capital fund co-investors to fund all the stages of their growth through industry leadership.

6. A significant portion of the Canadian venture capital industry, particularly in its early years, has been composed of government or quasi-government and government-sponsored funds, often with severe constraints limiting their investments to the geography of the funding jurisdictions. These restrictions, in turn, limited the deal flow and investment choices essential for funds to optimize investment performance and returns. In addition, misalign- 


\title{
Addressing Canada's Commercialization Crisis and Shortage of Venture Capital
}

\author{
Stephen A. Hurwitz
}

ments of interest often arose between the government funds' investment managers and the companies they invested in, because government fund-compensation structures often did not include the private-industry management performance upside benefits needed to strongly incentivize their investment managers to achieve the liquidity events (i.e., initial public offerings, mergers, or acquisitions) desired by the companies' management and privatesector investors.

No recovery can occur in the Canadian venture capital industry without solving, in particular, problems 2 and 5. Without institutional investors, there is no sustainable solution to the capital shortage in the Canadian venture capital industry. Although individuals and corporate investors play an important role in funding Canadian venture capital firms, the return to the market of giant institutional investors collectively possessing hundreds of billions of dollars available for investment in venture capital funds is key to a successful Canadian venture capital industry. Without large-scale funds, Canadian technology companies will have insufficient investor capital to participate in funding all the stages of their growth through industry leadership.

\section{Canada's 2013 Venture Capital Action Plan}

The federal government's solution to the shortage of venture capital is the 2013 Venture Capital Action Plan (tinyurl.com/obstvtw), which commits $\$ 400$ million and seeks to raise at least another $\$ 800$ million from outside investors. Of the $\$ 400$ million in federal funding committed under the plan, the federal government will put a total of $\$ 350$ million into four funds of funds, each of which is intended to be led by highly experienced private-sector investment managers, and \$50 million will be reinvested directly into venture capital firms. More specifically, that $\$ 400$ million financing will comprise:

- \$250 million for two new national funds of funds in the amount of $\$ 125$ million each

- \$100 million for recapitalizing two existing Canadian funds of funds in the amount of $\$ 50$ million each

- \$50 million for investment into three to five high-performing existing Canadian venture capital firms

The four funds of funds collectively will seek to raise at least an additional $\$ 800$ million from outside investors (especially institutional ones) for a total of $\$ 1.2$ billion, to be deployed over seven to ten years. The exact incentives the government will offer for other investors to invest $\$ 800$ million in the new funds of funds are expected to include creative ones such as the right of such investors to fulfill their capital commitments after the government fulfills its capital commitments and to receive returns on investment in advance of the government receiving its returns. To enhance the chances of success with the new funds of funds, the chosen investment managers are expected to be highly experienced and successful in their prior investments, and they are expected to commit their own capital. The funds of funds will focus primarily on early-stage investment (e.g., series A or B), with some growth equity and expansion capital investments throughout the lifecycle of their portfolio companies. See the later sub-section "Perpetuation of sub-scale venture capital funds" for a discussion of why this primary focus on early-stage investing will perpetuate Canada's late-stage financing problem if the new funds of funds do not invest primarily in large-scale venture capital funds. The exact investment strategies and the size and number of the funds of funds will depend on discussions with private-sector investors, and the investment strategies selected will be those that are expected to maximize participation from institutional and corporate strategic investors.

Investment managers of the new funds of funds, and of the venture capital firms they invest in, will be required to have a "substantial presence" in Canada, including a principal office engaged in active investing, with senior professionals meeting residency and other requirements. These conditions would allow foreign investment managers to open offices in Canada and partner with local ones in the new funds of funds and in the venture capital firms in which they invest. Foreign toptier investment managers who are selected would bring to Canada their network of significant relationships in major global customer and capital markets. They would also be bridges to the large higher-priced exits available in the United States and other foreign jurisdictions that have major capital markets.

Venture capital firms receiving capital from the new funds of funds will be required to invest at least a third of their total capital in Canadian-domiciled companies, with the remaining two-thirds investable anywhere in the world. This flexibility to invest outside of Canada will enable relationships with other foreign global investors and markets. These cross-border relationships, in turn, are expected to lead to those same foreign global investors co-investing in Canadian companies with the Canadian venture capital firms. 


\section{Addressing Canada's Commercialization Crisis and Shortage of Venture Capital}

\section{Stephen A. Hurwitz}

Thus, in the author's view, the Canadian government has developed the right plan to address Canada's venture capital shortage by:

1. Building a self-sustaining industry that will be led and funded by the private sector and will be marketand return-driven in its investment strategies.

2. Putting up substantial public funding to kick-start the venture capital industry, but playing no role in its investment management.

3. Selecting highly-experienced investment managers from the private sector with a history of successful investment performance.

4. Incentivizing the private sector with special incentives to fund the new fund of funds program in an amount greater than that provided by the government.

5. Structuring the new program so that well-connected, top-tier foreign investment managers can partner with Canadian ones in the new funds of funds.

6. Enabling broad latitude to invest outside of Canada to forge relationships with global investors and markets.

\section{Potential Peril for the 2013 Venture Capital Action Plan}

Phase out of federal tax credits for labour-sponsored venture capital funds

In its 2013 budget (tinyurl.com/paqlyqb), the federal government announced that, by 2017 , it would phase out all federal tax credits that currently incentivize individual investors to invest in labour-sponsored venture capital corporations (LSVCCs). The timing of this phase-out decision could not be worse. Although it is unclear to what extent various provinces will follow the federal government's lead and abandon their own LSVCC tax credits, or to what extent individual investors in the absence of tax incentives will cease investing in LSVCCs, the outcome for the Canadian venture capital industry is likely to be unfavourable. The federal government's decision could potentially result over time in a drop in available venture capital funding in Canada that exceeds the entire amount expected to be deployed under the 2013 Venture Capital Action Plan. This means that the plan could result in a net decrease in venture capital funds available to fund Canadian innovation.
More specifically, according to leading independent venture capital consultant Gilles Duruflé (2013; tinyurl.com/lbw5y6c), Quebec LSVCCs, currently representing over 75 percent of all funding by Canadian LSVCCs, on average invested per year over the 2006-2012 period: i) \$69 million in VC funding directly in technology companies and ii) $\$ 74$ million in private independent VC funds. This total of $\$ 143$ million per year invested from Quebec LSVCCs alone could by itself be roughly in the range of the amount per year ultimately to be deployed under the government's 2013 Venture Capital Action Plan (assuming it achieves the expected minimum $\$ 800$ million in outside investor funding). And, this $\$ 143$ million figure does not even take into account an additional \$58 million per year from Quebec LSVCCs in venture capital investments in traditional sectors over the same 2006-2012 period, bringing the total per year to $\$ 201$ million.

LSVCCs have been major players in Canada in funding companies backed by venture capital and private-sector venture capital funds (Duruflé, 2013; tinyurl.com/ lbw5y6c):

1. Beginning in 2004, there was a major shift of Quebecbased LSVCCs and certain Quebec-based institutional investors from investing directly in companies to investing in venture capital funds. For a significant number of Canadian private independent funds raised in the last decade, LSVCC funding directly or indirectly played a critical role without which it would have been very difficult for these private funds to have achieved a first closing.

2. From 2004 to 2012, $\$ 5.7$ billion was raised by Canadian private independent funds, of which $\$ 2.5$ billion (45\%) included a contribution from LSVCCs.

3. Quebec LSVCCs have committed $\$ 830$ million to 59 private independent funds within Quebec and across and outside of Canada.

Although LSVCCs, particularly in their early years, have been justifiably criticized for various structural, management, and performance deficiencies (some of which have since been ameliorated), their diminished presence in the marketplace by 2017 could imperil the success of the 2013 Venture Capital Action Plan by depriving the four funds of funds, and the venture capital firms in which they invest, of critically needed LSVCC co-investment capital. 


\title{
Addressing Canada's Commercialization Crisis and Shortage of Venture Capital
}

\author{
Stephen A. Hurwitz
}

This problem is further compounded by the possibility that the $\$ 1.2$ billion to be deployed under the 2013 Venture Capital Action Plan over seven to ten years may itself be insufficient even if LSVCC tax credits were not being phased out. Because it can often take at least two successive successful fundings to ensure future self-sustaining fundings for a venture capital firm's management team, another significant federal financial commitment beyond that in the 2013 Venture Capital Action Plan might still be needed toward the end of the initial ten-year deployment period. On a positive note, the government could always add additional funds at that time if deemed appropriate.

\section{Perpetuation of sub-scale venture capital funds}

Another challenge facing the 2013 Venture Capital Action Plan is the sub-scale size of most existing Canadian venture capital firms. If the 2013 Venture Capital Action Plan does not result in a substantial increase in the average size of venture capital firms to be funded in the future, the Canadian venture capital industry may not recover.

In its 2012 Economic Action Plan (tinyurl.com/8a55cu4), the Canadian government highlighted the need to support the creation of "large-scale venture capital funds", meaning in the $\$ 200$ to $\$ 300$ million range. However, when the government further detailed this goal in its 2013 Venture Capital Action Plan, it instead referred to large-scale funds of funds. Most observers missed this critical distinction. In addition, because of the significant anticipated reduction in LSVCC investment capital as a result of phased out federal tax credits, the four funds of funds may not have the direct and indirect LSVCC co-investment funding needed to finance largescale venture capital funds and the technology companies in which they invest. This means that one of the most serious existing flaws in the Canadian venture capital industry - the preponderance of sub-scale venture capital funds - not to mention the shortage of venture capital generally, may be perpetuated.

Why are large-scale venture capital funds so critical for investment success? Studies have shown that VC firms in the $\$ 200$ to $\$ 300$ million range have the strongest performance over time, and those that are smaller are less successful (BDC, 2010; tinyurl.com/7wg7ouw). In Canada, the average venture capital fund is well below $\$ 100$ million; however, for Canada, approximately $\$ 200$ million is the right size for its venture capital funds, for the following reasons. Large-scale venture capital funds of this size possess:
1. The capital necessary to finance promising technology companies through all the stages of their growth through industry leadership. They are lifecycle investors.

2. The financial heft to provide the competitive compensation needed to attract and retain highly experienced professional venture capital managers with proven records of performance.

3. The financial resilience to weather the economic downturns and droughts in initial public offerings, mergers, and acquisitions that are certain to occur over a venture capital firm's 10 to 12 year life. Without financial strength, small venture capital firms will often fail because they have insufficient funds to provide extended financing during protracted economic downturns.

4. The ability to attract investment from institutional investors, which are unlikely to invest in sub-scale funds.

5. The ability to attract deep-pocket US co-investors and thus can leverage their existing funding on a significant scale. They can assuage the concerns of US venture capitalists who are often reluctant to co-invest with Canada's small sub-scale funds. US venture capitalists justifiably worry that, although Canada's small funds may have capital for early-stage investing, when it comes time for critical late-stage financing infusions, they often fall short.

6. The financial strength to reduce the vulnerability of many small Canadian venture capital funds stemming from their over-dependence on large US venture capitalists, who cherry-pick many of Canada's large-dollar, late-stage financings. US venture capitalists generally invest in at least $10 \%$ of Canadian venture capital deals by Canadian companies comprising $31 \%$ of exits and $44 \%$ of exit proceeds (BDC, 2010; tinyurl.com/7wg7ouw). That harmful overdependency reflects the financial inability of small Canadian venture capital funds to participate in these late-stage financings and results in devastating dilution of their early investments.

7. The potential to spur angel and early-stage investing by giving these investors confidence that significant venture capital follow-on funding would be available for their companies. 


\section{Addressing Canada's Commercialization Crisis and Shortage of Venture Capital}

Stephen A. Hurwitz

\section{Conclusion}

Canada's 2013 Venture Capital Action Plan is both bold and innovative. However, two dark clouds loom: i) the detrimental timing of the government's phase out of federal LSVCC tax credits (at least as relating to direct or indirect VC investments by LSVCCs) and ii) the related uncertainty as to whether the underlying Canadian venture capital firms financed under the 2013 Venture Capital Action Plan will be large enough to successfully regenerate Canada's venture capital industry.

The success of the 2013 Venture Capital Action Plan could well hinge on whether the government can solve these problems. The government should rescind its phase out of LSVCC tax credits and not revisit that issue until its 2013 Venture Capital Action Plan has succeeded in jump-starting a robust, self-sustaining, private-sector venture capital industry. In addition, the investment managers selected by the government for the funds of funds need to understand in developing their investment strategies the importance of largescale venture capital funds for a successful venture capital ecosystem.

If these problems are addressed, the 2013 Venture Capital Action Plan will offer a promising, albeit still challenging, path to achieving a critical missing requirement for a successful Canadian innovation ecosystem: a venture capital industry led and funded by the private-sector with the capital and investment expertise to successfully commercialize Canada's outstanding $R \& D$ into world-class products, high-quality jobs, and robust exports.

\section{About the Author}

Stephen Hurwitz is a partner at the Boston-based law firm of Choate, Hall \& Stewart LLP, specializing in Canada-US cross-border transactions involving venture capital and private equity and technology and life sciences companies. He has served as a speaker/panelist at many of the venture capital, technology, and life sciences conferences in Canada and is author of numerous published articles on the Canadian venture capital ecosystem. He has also served as visiting lecturer on venture capital and emerging technology company issues at the MIT Sloan Entrepreneurship Development Program, Harvard Business School, and Harvard Law School. He is co-founder of the non-profit Quebec City Conference, an annual by-invitation only international gathering of leading venture capital, private equity, and institutional investors. Mr. Hurwitz received an A.B. from Cornell University and a J.D. from Cornell Law School.

Citation: Hurwitz, S.A. 2013. Addressing Canada's

Commercialization Crisis and Shortage of Venture Capital: Will the Federal Government's Solution Work?

Technology Innovation Management Review. September 2013: 26-31.

Keywords: VC, venture capital, Canada, 2013 Venture Capital Action Plan, labour-sponsored venture capital corporations, commercialization 